\title{
Critical thinking education in the portuguese higher education institutions: a systematic review of educational practices
}

\author{
Gonçalo Cruz, Rita Payan-Carreira \\ \& Caroline Dominguez
}

\begin{abstract}
Critical Thinking (CT) education has been a field of growing concern within the Portuguese Higher Education (HE) context, in an attempt to meet the labour market needs and the most demanding and complex societal challenges. However, there is a lack of systematic literature review studies characterizing the different CT educational practices adopted by faculty teachers. Thus, this review intends to understand to what extent the Portuguese teachers in HE have been developing CT skills and dispositions in their students, in a continuous, explicit and effective way. Following the steps of review methods, 27 empirical studies complying with the inclusion criteria were analysed. Results show that CT educational practices are gradually increasing over the years, but they tend to be developed with an implicit, non-intentional and short-term basis, neglecting the development of CT dispositions in the classroom. Studies from different nature are needed (experimental, longitudinal) in order to assess the permanency or generalization of CT in students. Several difficulties were found and future work should stimulate the discussion on the ways to overcome them, guiding HE teachers and institutions in the development, support and evaluation of CT practices.
\end{abstract}

Keywords:

higher education; critical thinking; educational practices; literature review 


\section{A educação do pensamento crítico no ensino superior em Portugal: uma revisão sistemática de práticas educativas}

Resumo: A educação do Pensamento Crítico (PC) tem sido uma preocupação crescente no contexto do Ensino Superior (ES) português, tanto para satisfazer as necessidades do mercado de trabalho, como para responder aos desafios societais cada vez mais complexos. No entanto, há ainda uma carência de estudos sistemáticos de revisão da literatura que caracterizem as diferentes práticas educativas de PC adotadas pelos docentes universitários. Assim, a presente revisão pretende compreender em que sentido os docentes portugueses do ES têm desenvolvido competências e disposições de PC nos seus alunos, de forma contínua, explícita e eficaz. Seguindo as etapas de métodos de revisão da literatura, foram analisados 27 estudos empíricos. Os resultados mostram que, embora as práticas educativas de PC tenham aumentado gradualmente ao longo dos anos, as mesmas tendem a ser adotadas de forma implícita, não-intencional e em curtos períodos de tempo, desvalorizando o desenvolvimento de disposições de PC em sala de aula. Verifica-se a necessidade da existência de estudos complementares (experimentais, longitudinais), a fim de avaliar a permanência ou generalização do PC nos estudantes. Trabalhos futuros deverão estimular uma discussão mais aprofundada sobre como superar as dificuldades encontradas, orientando docentes e instituições de ES no desenvolvimento, suporte e avaliação de práticas educativas de PC. Palavras-chave: ensino superior; pensamento crítico; práticas educativas; revisão da literatura

\section{L'éducation de la pensée critique dans l'enseignement supérieur au Portugal: une révision systématique des pratiques éducatives}

Résumé: L'éducation à la Pensée Critique (PC) est un domaine de préoccupation croissante dans le contexte de l'Enseignement Supérieur (ES) portugais, pour répondre soit aux besoins du marché de travail, soit aux défis de plus en plus complexes de la société. II existe cependant un manque d'études systématiques de révision de littérature qui caractérisent les différentes pratiques éducatives de la PC adoptées par les facultés. Ainsi, ce travail a l'intention de comprendre dans quelle mesure les enseignants portugais de l'ES développent des compétences et des dispositions de la PC chez leurs étudiants, d'une manière continue, intentionnelle et efficace. En suivant les étapes des méthodes de révision de littérature, 27 études empiriques ont été analysées. Les résultats montrent que, bien que les pratiques pédagogiques de la PC se développent, elles tendent à être adoptées implicitement, de manière non-intencionelle et sur des périodes de courte durée, minimisant le potentiel de développement de la PC. II existe un besoin de plus d'études complèmentaires (expérimentales, longitudinales) afin d'évaluer la permanence ou généralisation de la PC chez les étudiants. Les travaux futurs devraient stimuler une discussion approfondie sur la manière de surmonter les difficultés rencontrées, orienter les enseignants et les établissements de l'ES dans le développement, le soutien et l'évaluation des pratiques éducatives de la PC.

Mots-clés: éducation supérieure; pensée critique; pratiques éducatives; révision de la littérature

\section{La educación del pensamiento crítico en la educación superior en Portugal: una revisión sistemática de prácticas educativas}

Resumen: La educación en Pensamiento Crítico (PC) ha sido un campo de creciente preocupación dentro del contexto de la Educación Superior (ES) portuguesa, en un intento de satisfacer las necesidades del mercado de trabajo, y atender a los complejos desafíos sociales. Sin embargo, existe una carencia de estudios sistemáticos de revisión bibliográfica que caracterizan las diferentes prácticas educativas adoptadas por el profesorado. Por lo tanto, esta revisión intenta comprender en qué medida los profesores portugueses de ES han estado desarrollando habilidades y disposiciones de PC en sus alumnos, de manera continua, explícita y efectiva. Siguiendo los pasos de los métodos de revisión, se analizaron 27 estudios empíricos. Los resultados muestran que, aunque las prácticas educativas de PC han aumentado gradualmente, las mismas tienden a ser adoptadas de forma implícita, no intencional y de corta duración, desvalorizando el desarrollo de disposiciones de PC. Se observa la necesidad de más estudios complementares (experimentales, longitudinales), a fin de evaluar la permanencia o generalización del PC en los estudiantes. Los trabajos futuros deberán estimular una discusión más detallada sobre cómo superar las dificultades encontradas, orientando docentes e instituciones de ES en el desarrollo, soporte y evaluación de prácticas educativas de PC.

Palabras clave: pensamiento crítico, educación superior, prácticas educativas, revisión de la literatura 


\section{Introduction}

Employers frequently complain about the existing gaps between the graduates' competency profiles and the labour market needs, namely in the so called "soft skills" (Schwab \& Samans, 2016). In response, some generalist CT subjects have been included in HE curricula, and new pedagogical methods adopted, promoting a closer collaboration with experts and companies for forthcoming curricula reforms and redefinition of learning outcomes (McAleese et al, 2013).

Even though underlined by educational policies, the opportunities to develop CT skills are scarce and undervalued within the HE curricula, which mainly stress memorization, retrieval and a passive transfer of knowledge (DiCarlo, 2009). It is still controversial whether or not the offer for specific semi-annual courses on CT generalities is sufficient to bridge the existing gaps (Ennis, 2016) since, according to Arum \& Roksa (2011), students' gains in CT are either exceedingly small or empirically non-existent.

The inexistence of review studies concerning the pedagogical strategies used by teachers in HEl fostering the development of desirable soft skills supports the need to systematize what is being done to foster CT in HE students. In the scope of the European project CRITHINKEDU "Critical Thinking across the European Higher Education" and through a systematic review of the literature, this study aims to identify and analyse the pedagogical practices used by teachers in Portuguese universities to develop CT skills and dispositions with their students and to reflect on their continuous intentional effectiveness.

\section{Critical Thinking in Higher Education}

CT has been conceptualized in terms of attitudes, processes, purposeful reflection, skills and dispositions, competences or developmental process. Ennis (1991) defined CT as a "reasonable reflective thinking focused on deciding what to believe or do" ( $\mathrm{p}$. 6) stressing the logical process involving purposeful reflection, while Facione (1990, p.

2) conceptualized it as a set of skills and dispositions:

We understand critical thinking to be purposeful, self-regulatory judgment which results in interpretation, analysis, evaluation, and inference, as well as explanation of the evidential conceptual, methodological, criteriological, or contextual considerations upon which that judgment is based (...) The ideal critical thinker is habitually inquisitive, well-informed, trustful of reason, open-minded, flexible, fair-minded in evaluation, honest in facing personal biases, prudent in making judgments, willing to reconsider, clear about issues, orderly in complex matters, diligent in seeking relevant information, reasonable in the selection of criteria, focused in inquiry, and 
persistent in seeking results which are as precise as the subject and the circumstances of inquiry permit.

Recognizing the importance of dispositions (e.g., open-mindedness, self-confidence or willingness to inquire), the Facione's concept was adopted in this study. As Hamby (2015, p. 86) argued, "People who lack this basic drive and (...) other important virtues are not the kinds of thinkers we aim to educate, and should not be called critical thinkers, whatever their intellectual skills (...)". This applies also to teachers, who need to be humble towards their knowledge, accepting that their positions can be questioned, and open to consider the importance of students as actors in the discussion and debate of key topics within a field (Barnett, 2015).

The key question on whether a separate course or CT should exist or if CT should be embedded in standard courses remains actual. Different approaches exist, showing the disagreement on whether CT is a set of generic skills that apply across subject domains (and therefore should be taught in specific CT courses) or if it is dependent on the subject matter.

Although other classifications of CT education approaches exist (Saiz \& Rivas, 2017), the one proposed by Ennis's (1989), provides a helpful framework to researchers and professionals (Figure 1):

Figure 1 - The four approaches to CT education (Ennis, 1989)

General approach
- The abilities and
dispositions are taught
separately from the
subject content
- Usually taught in
independent disciplines
- Typically teach only
traditionally highlighted
aspects of critical
thinking (ex. formal or
informal logic)

Infusion approach
- Consists in a subject
matter instruction
- St u d e $\mathrm{n} \mathrm{s}$ a re
encouraged to think
critically about the
subject addressed in a
course/discipline
- The general principles
of $\mathrm{CT}$ are made explicit
and the content of the
course is important
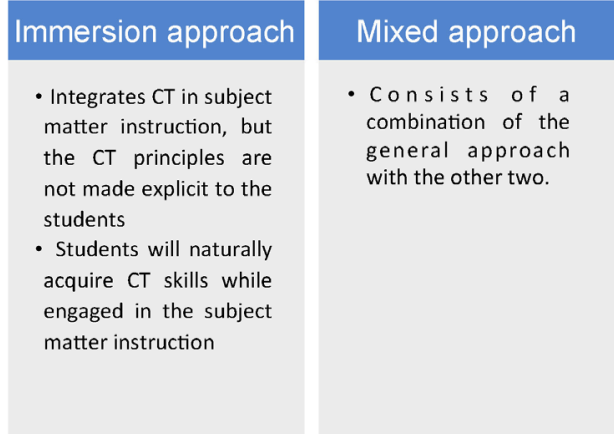

Believing that CT can be taught and learned, several authors (e.g. Tiruneh, Verburgh \& Elen, 2014) highlight the efforts of educators to foster CT among students. CT is slowly nurtured in general school education through specific instructional interventions. Problem-based learning (PBL), for example, is one of the most widely learning approach that appears to consistently result in greater CT improvement (Tiruneh et al., 2014), provided that students are involved in investigating, developing, testing, discussing hypotheses or solutions Ennis (2016). Other learning strategies similar to PBL exist 
([e.g., hands-on learning, scenario-based learning, or case studies (Tiruneh et al., 2014; Payan-Carreira, Dominguez, Monteiro, \& Rainho, 2016)], which are student-centered and request that students assume an active role to solve a real-life related problem or take a position. These strategies may also integrate other approaches, as it happens in 'DIAPROVE' (Saiz \& Rivas, 2017), a short-term CT program focusing on argumentation as an integrator mechanism of different CT skills, which combines direct instruction, PBL, group work activities and expectancy-value motivational techniques.

Abrami et al. (2015, p. 289), using the Facione's (1990) CT definition, developed a set of four categories of instructional interventions (Figure 2).

Figure 2 - The four categories of instructional interventions (Abrami et al, 2015)

\begin{tabular}{|c|c|}
\hline Self-learning & Dialogue \\
\hline $\begin{array}{l}\text { - Includes instructional } \\
\text { techniques and learning } \\
\text { activities centered in } \\
\text { students' individual } \\
\text { work. } \\
\text { - Occurs when the } \\
\text { students study alone, } \\
\text { engaged in reading, } \\
\text { watching, listening to a } \\
\text { teacher's explanations, } \\
\text { reflecting on new } \\
\text { information, or solving } \\
\text { abstract problems on } \\
\text { their own. }\end{array}$ & $\begin{array}{l}\text { - Uses the discussion as a } \\
\text { didactic strategy to } \\
\text { facilitate CT } \\
\text { - Occurs when students } \\
\text { discuss a particular } \\
\text { problem together, } \\
\text { assuming an adversarial } \\
\text { o r c o o p e r a ti v e } \\
\text { positioning, using some } \\
\text { sort of question as a } \\
\text { starting point. } \\
\text { - Can show multiple forms } \\
\text { (e.g., whole-class debates, } \\
\text { in-groups discussions and/ } \\
\text { or online discussion } \\
\text { forums. }\end{array}$ \\
\hline
\end{tabular}

Authentic or
Anchored Instruction
- Presents the students
with genuine problems
or problems that make
s ense to the $\mathrm{m}$,
engaging them and
stimulate them to
inquiry.
- This category includes
simulations and role-
playing, and several
kind of dilemmas (eg.,
medical, ethical) to be
explored by students.

Mentoring
- Mentoring emphasizes
modelling and error
correction based on
critical analysis.
Inte grate $\mathrm{s}$ he
interaction between
an expert or someone
with more expertise,
and a novice or
someone with less
expertise.
- It may assume diverse
forms (One-on-one
mentoring, tutoring,
$\mathrm{c}$ o a c $\mathrm{h} i \mathrm{n}$,
apprenticeship or
modelling)

However, the research on their effectiveness is limited. Some reasons associated to their ineffectiveness include the existence of a predominant lecture-centered instruction, the lack of teachers' knowledge on the use of learning strategies enabling students to think analytically through content or teach content as thinking (Paul, 2005), or even the short-term memorization focused in getting high grades (DiCarlo, 2009). Also, teachers may be unable to integrate CT concepts to the discipline content, or simply ignore how to do it effectively (Tiruneh et al., 2014).

This may also be a reality in Portuguese HE in the last years. Even though CT is being included in some of the educational curricula (as exposed in Dominguez et al., 2015), it remains far from been projected widely into a systematic and intentional development of CT abilities. To reverse this reality, we need to change the idea that all students develop their abilities naturally and spontaneously. Furthermore, although CT is one of the most cited skills by Portuguese HEl study programs (e.g. mission, 
curricula, discourses), its meaning remains unclear, and teachers are unfamiliar with the strategies allowing its development (Soares, Franco, \& Dias, 2017). A lack of in-depth studies on how CT can be operationalized remains, and additional efforts are needed to better understand which CT assessment instruments may be more adequate to adopt and validate the educational strategies for CT development (Franco \& Almeida, 2017).

In relation to CT assessment and following use, three relevant aspects need to be pondered (Saiz \& Rivas, 2017): acquisition, permanency and generalization (Figure 3). Acquisition and generalization of CT skills tends to be more difficult to measure and verify.

Figure 3 - Three major aspects to consider when assessing CT development

(Saiz \& Rivas, 2017)

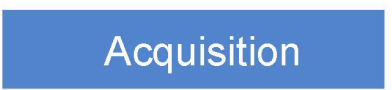

The ability to learn CT skills/dispositions, which can be measured through the design of studies and interventions with a control group and the use of a pre/posttest for level assessment

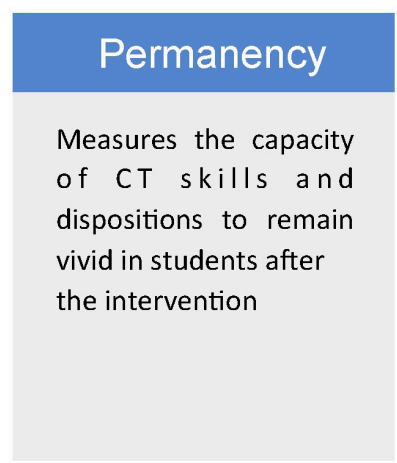

Several instruments are available to evaluate CT, categorized according to different elements (Franco \&Almeida, 2017): the target audience, the dimensions of analysis (one or multidimensional), the assessment format (multiple choice or open answer items), and the content (more or less related to everyday life). According to its complexity, CT assessment takes time and effort from teachers and researchers, because it requires the development of specific assessments instruments and/or rubrics. More research is needed on this dimension.

\section{Research Method}

This review aims: 1) to gather and analyse information on the teaching practices and interventions adopted by Portuguese HEI to promote CT skills and dispositions in students; 2) to determine if they promote CT in a continuous, explicit and effective way.

A systematic literature review of empirical peer-reviewed publications from Portuguese authors was performed, following the four steps of systematic reviews in Science Education, (Bennet, Lubben, Hogarth \& Campbell, 2005). 
Figure 4 - Synthesis of the methodological approach used for the systematic literature review

\begin{tabular}{|c|c|}
\hline $\begin{array}{l}\text { Electronic Database } \\
\text { used }\end{array}$ & $\begin{array}{l}\text { B-on Knowledge Library* } \\
\text { RCAAP (Portuguese Scientific Open Access Repository) } \\
\text { Scopus } \\
\text { SciELO (Scientific Electronic Library Online) } \\
\text { RACO (Catalan Journals in Open Access } \\
\text { Redalyc (Red de Revistas Científicas de América Latina y el Caribe, España y } \\
\text { Portugal). } \\
\text { Manual search for publications from the two last main international conferences held } \\
\text { in Portugal on the topic }\end{array}$ \\
\hline Keywords & $\begin{array}{ll}\text { [in Portuguese] } & \text { [in English] } \\
\text { Pensamento critico } & \text { Critical thinking } \\
\text { Ensino superior } & \text { Higher education } \\
\text { Competências } & \text { Skills } \\
\text { Atitudes } & \text { Attitudes } \\
\text { Disposições } & \text { Dispositions } \\
\text { Intervenções } & \text { Interventions } \\
\text { Estratégias } & \text { Strategies } \\
\text { Práticas } & \text { Practices }\end{array}$ \\
\hline Boolean sentences & $\begin{array}{l}\text { "Critical thinking AND (skills OR dispositions OR attitudes) AND (Higher education } \\
\text { OR universities OR faculties) AND (Interventions OR strategies OR practices)". }\end{array}$ \\
\hline $\begin{array}{l}\text { Restrictive filters } \\
\text { 2. Selection of pul }\end{array}$ & $\begin{array}{l}\text { Country }=\text { Portugal or Affiliation=Portugal } \\
\text { ions on CT for analysis }\end{array}$ \\
\hline Inclusion criteria & $\begin{array}{l}\text { Studies enrolling students in HEI } \\
\text { Studies published in either Portuguese or English, including Doctoral thesis } \\
\text { Empirical educational interventions } \\
\text { Full text available } \\
\text { From } 2000 \text { to } 2016 \text { (December) }\end{array}$ \\
\hline $\begin{array}{l}\text { Exclusion criteria } \\
\text { [upon screening of } \\
\text { the abstracts] }\end{array}$ & $\begin{array}{l}\text { Review papers } \\
\text { Non-peer reviewed articles } \\
\text { Publications not related with higher education } \\
\text { Non-intervention studies or the absence of methodological quality criteria } \\
\text { Non-specification or inexistence of assessment methods used to evaluate the } \\
\text { improvement of CT skills in participants }\end{array}$ \\
\hline Rubric for analysis & $\begin{array}{l}\text { Eleven dimensions considered, according to Facione's categories }(1990, \mathrm{p} .2) \text { : } \\
\text { The type of study; type of program; field of knowledge; CT aims; the overall } \\
\text { approach; the specific type of intervention; the teaching strategies; the learning } \\
\text { material; the learning results; the evaluation of learning and the reported difficulties }\end{array}$ \\
\hline To identify: & $\begin{array}{l}\text { - the field and level of HE represented in the studies and the methodological } \\
\text { approach used } \\
\text { - the instructional methods and resources used for promoting CT practices }\end{array}$ \\
\hline \multicolumn{2}{|c|}{ 4. Synthesis and quantitative data } \\
\hline To determine & $\begin{array}{l}\text { - The reported CT practices in Portuguese academic publications } \\
\text { - To identify patterns and distribution of papers according to the field and HE level } \\
\text { addressed } \\
\text { - To identify the instructional approach and learning materials used in CT } \\
\text { promoting practices }\end{array}$ \\
\hline
\end{tabular}

Figure 5 summarises the process used for the systematic literature review. The title and abstracts were carefully read, analysing each one against the inclusion and exclusion criteria. Literature search provided 90 records; after exclusion of duplicates 
and non-eligible papers a total of 33 full papers were screened. Six more papers were discarded for not meeting quality criteria, narrowing the final set of analysed articles to a total of 27.

Figure 5 - Flow diagram for the literature review

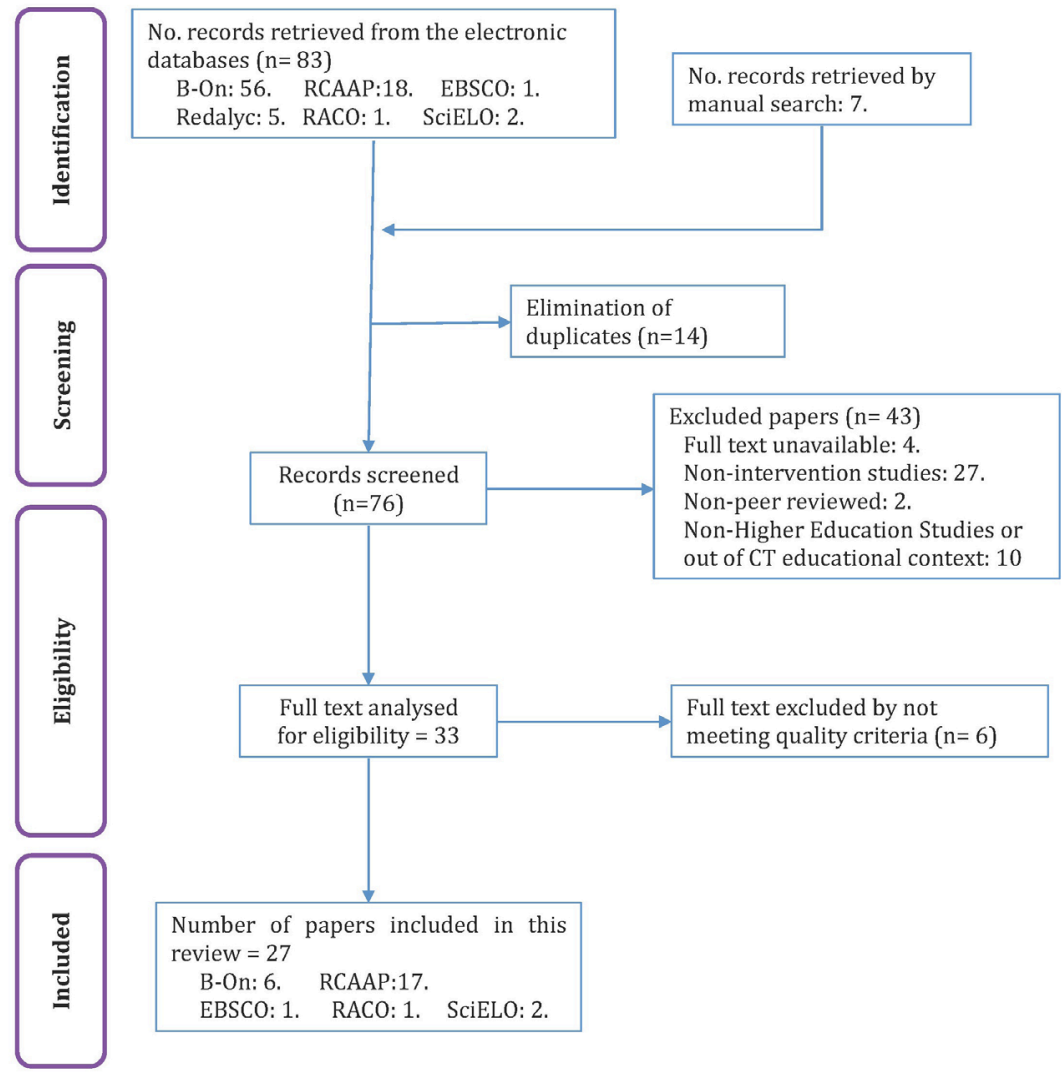

An ID code was assigned to each paper, according to four categorized fields of study used in this work (STEM - Science, Technology, Engineering and Mathematics; SS - Social Sciences; BS - Biomedicine Sciences; and G - General, transversal to multiple fields). 


\section{Results}

A total of 27 papers were selected for systematic content analysis (Figure 6). The largest number of papers analysed $(n=17 ; 63 \%)$ came from RCAAP database. Most of the retrieved papers were published in the last decade, from 2007 to 2016, with only one in 2003 and another in 2004. Ten were written in English and 17 in Portuguese. Nine of the 27 studies were published in renowned indexed journals or databases.

Figure 6 - Short-list of the 27 papers fully analysed (detailed information available at http://bit.ly/2v286NP)

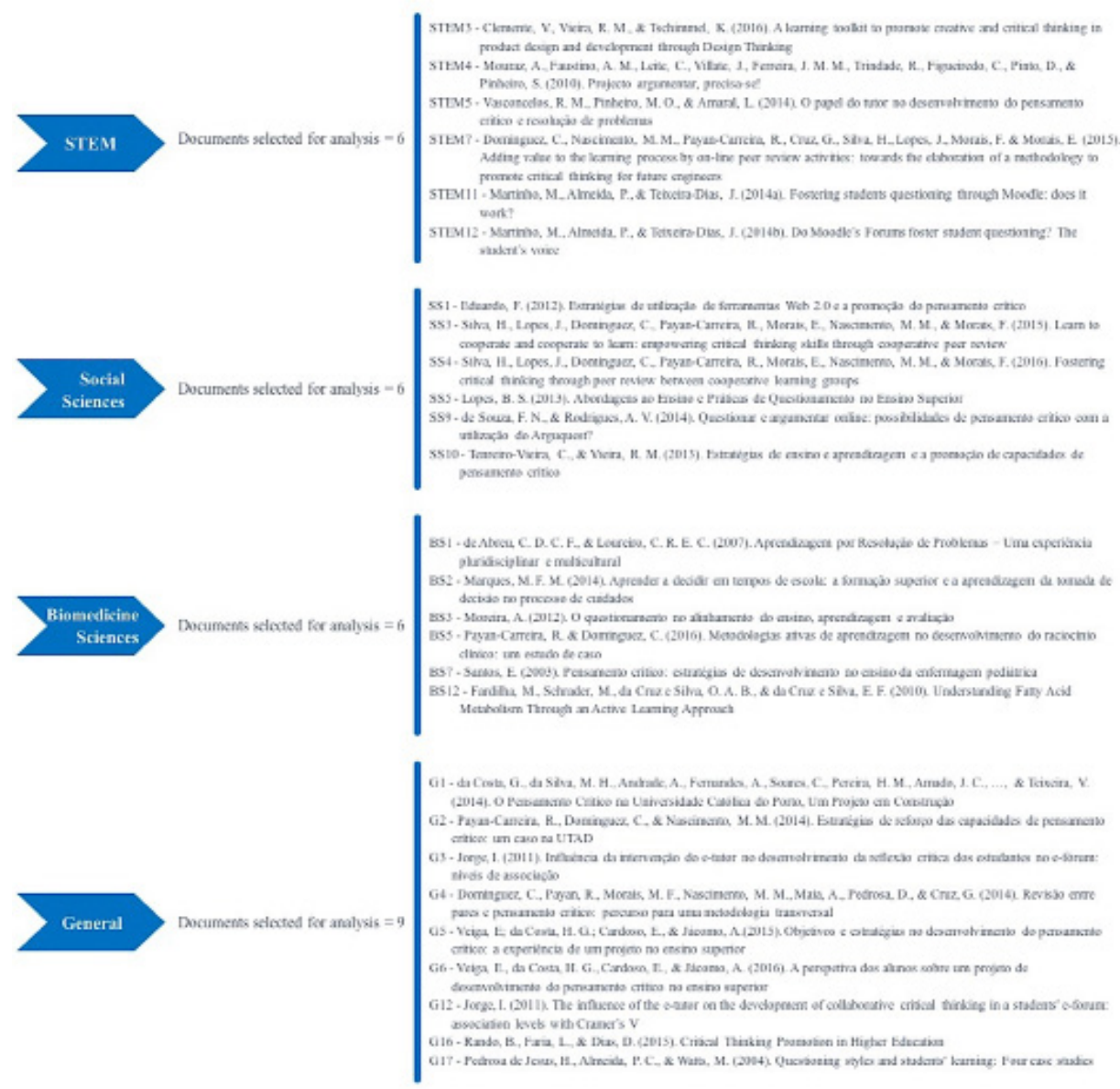


3.1. Knowledge Fields, Levels of Study and Research Methods of the selected papers

The 27 studies covered the following fields: STEM - Science, Technology, Engineering and Mathematics (e.g. Civil, Textile or Production Engineering; $n=6$ ); SS - Social Sciences (e.g., Education; $n=6$ ); BS - Biomedicine Sciences (e.g. Nursing and Veterinary Medicine; $n=6)$; and $G$ - General $(n=9)$, covering multiple fields, not only STEM or Social Sciences, but also Biomedicine Sciences (e.g. Engineering, Biotechnology, Law and Arts), including two publications from the same author (G3 and G13) not specifying the fields addressed in the studies. In Figure 7, a quantitative summary of the results is provided, following the principal dimensions adopted for the analysis.

Figure 7 - Quantitative results for the pedagogical strategies to develop CT skills in Portuguese HE students [Number of papers analysed $=27$ ]

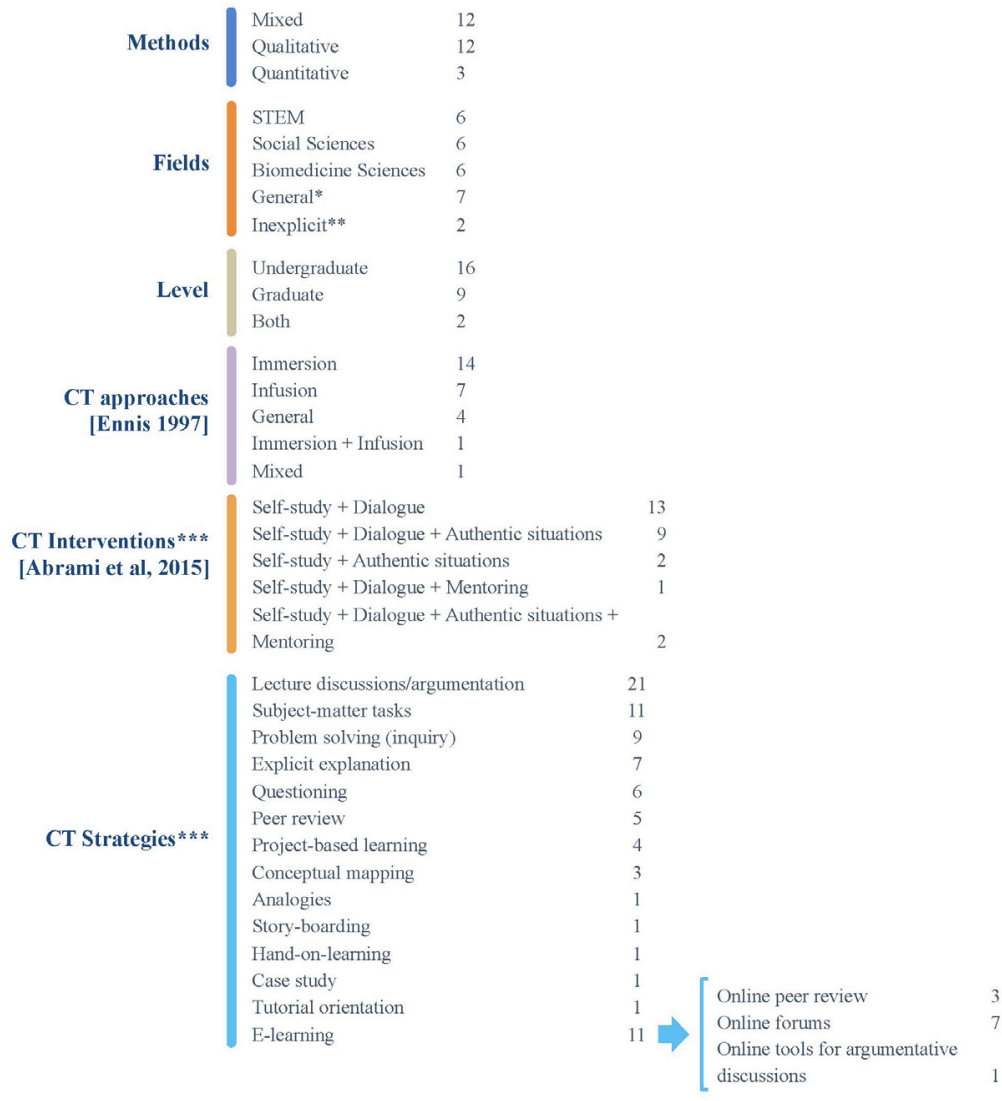

*Publications reporting interventions across multiple fields; ** publications that do not specify the fields of study addressed in the interventions; *** publications always reported a combination of different CT interventions and strategies 
The studies retrieved often used a mixed and/or qualitative research methodology $(n=24)$ to report the educational/empirical interventions (case studies, action-research, focus groups interviews and questionnaires); only three used quantitative methods research (e.g., statistical analysis of the students' assignments). Two studies adopted an experimental methodology of research with both control and experimental groups (STEM3 and SS10). All the publications represent short-term interventions corresponding to academic semesters. Almost $60 \%$ of the publications described CT educational practices developed with undergraduate students, while around 33\% relate to graduate students; the remaining two studies involved both graduate and undergraduate students.

\subsection{Approaches, Interventions and Strategies}

Concerning the CT approaches (Ennis, 1989), most of the studies $(n=14)$ used the Immersive approach, while the remainder portrayed the Infusion $(n=7)$ or the General approach $(n=4)$. One study established a comparison between the Infusion approach associated with CT-driven strategies (i.e., questioning, debates or problem-based learning) and the Immersion's using strategies not specifically CT oriented (SS10); the results highlighted significant differences in students submitted to the two approaches.

All the studies adopted Self-learning as the main CT intervention (Abrami et al., 2015). It was often complemented with more than one CT intervention: Dialogue $(n=20)$, Authentic situations $(n=10)$ and Mentoring $(n=1)$.

Regarding the CT strategies, Lecture discussions (argumentation) prevailed $(n=21)$ over 'Subject-matter tasks/writing articles, reports and other assignments' ( $n=11)$, 'Problem solving/inquiry' ( $n=9$ ), 'Explicit explanation' ( $n=7)$; 'Questioning' $(n=6)$, 'Peer review' ( $n=5)$, 'Project-based learning' $(n=4)$ and 'Conceptual mapping' $(n=3)$. A large number of studies $(n=22)$ combined one or more CT teaching strategies with different intensity and frequency of use, while only five reported a unique CT strategy. Eleven studies integrated E-learning technologies to enhance CT skills, in two main formats (distance or blended learning) and with different strategies (peer review, forums, argumentative discussion, etc.).

\subsection{Pedagogical objectives for CT education}

In all the studies, the pedagogical interventions intent to promote CT skills (also named as reflexive skills and critical reflection in G3 and G12; higher order thinking skills in BS12; or analytical and reflexive thinking in BS1 and SS5), viz. interpretation, analysis, synthesis or evaluation (BS2, G4, SS1, SS10, BS5, BS12, BS1, STEM3); explanation or questioning (BS3, SS9, STEM11, SS5 and STEM12); argumentation (SS1, SS9, STEM4 and G16); and metacognition (STEM3). Some publications presented results related to CT dispositions, but only a few initially aimed at fostering them on 
students (only STEM3, SS1, SS9 and SS10, or the CT affective domain in nursing BS7). Other skills related to CT, such as decision-making (BS2, SS1, SS9 and G17), problem-solving (SS5, G17, STEM5 and BS1), creativity (STEM3) and interpersonal skills (STEM4, STEM7, G2 and G4), were also mentioned as objectives for the interventions.

The theoretical frameworks underlining those interventions were mostly based on Ennis CT abilities and dispositions taxonomy (Ennis, 2016), in papers SS1, SS9, SS10, BS5, STEM3, STEM7, SS3, SS4, G2 and G4. Besides Ennis's, other frameworks were used, namely the CT elements of thought (Paul, 2005), in G1, G5 and G6; the Nosich's CT elements (Nosich, 2011), in G5 and G6; the SOLO taxonomy (Biggs and Collis, 1982) in SS9; the Nelson \& Schunn' s feedback model (2009), in STEM7, SS3, SS4, G2, and G4. Furthermore, in some studies, CT aims were properly contextualized and based on frameworks related to the field of knowledge, especially in Biomedicine Sciences (e.g. BS2 and BS7) or STEM (e.g. STEM3) - in which CT is intrinsically related to clinical reasoning/judgment or creative skills (e.g. Scheffer \& Rubbenfield, 2000; de la Torre, 1991).

\subsection{Learning Materials}

From the different learning materials currently available to promote CT skills and dispositions [e.g. problematic situations, intervention or clinical scenarios, videos, research papers, published articles, research assignments, written reports, conceptual maps, online tools, or questioning grids, among others], the learning materials identified in this review seemed strongly related to the CT approaches, interventions and strategies. For instance, the 'Infusion' approach was associated with the adoption of explicit explanation/direct instruction CT teaching strategy, as well as with the use of learning materials and tasks oriented to CT (e.g. use of the FRISCO grid, or its adapted version, in developing the learning task; STEM7, G2, G4, BS5 and STEM3). Conversely, in the case of the 'Immersion' approach, teachers tend to use more subject-related resources and tasks not specifically oriented to CT, such as tests/exams, research assignments, simulation reports or other written assignments in which students' must take a position (STEM4, STEM11, STEM12, among others).

\subsection{CT Assessment and Learning Results}

The Assessment and Learning Results of CT dimensions were characterized by qualitative and/or quantitative analysis of students' CT skills, based on the collection of different data, such as the engagement with the learning artefacts and materials, and/ or the teachers' and students' perceptions (e.g. STEM4, STEM5, STEM7, SS9, BS1, BS2, BS3, BS7, G1, G3, G5, G6). These studies ( $n=12)$ not only considered the CT interventions successful (as they acknowledge the students' CT improvements) since 
students engage with the learning assignments, materials or artefacts (STEM7, SS9, STEM4, BS7) but they also identify students' positive attitudes toward CT development (BS12, BS1, G1, G5, G6), the relevance of the teachers' role (SS5, BS1, BS3, G3), or the value of peers in the learning process (STEM5, STEM7, SS3, SS4, BS1).

Few studies ( $n=5)$ adopted formal CT assessment instruments to measure the effect of CT interventions on the development of skills and dispositions, through the application of pre- and post-activity tests, such as the Cornell Critical Thinking Test (CCTT) - Level X (Ennis, 2016), in STEM3, SS10, STEM7, G2 and G4, or the TAEC Creativity Test (de la Torre, 1991) in STEM3. Although the majority of these studies presented positive results based not only on pre/post-test results, but also by analysing the learning artefacts, performance or perceptions, the results were not always positive (STEM3 and STEM7). In STEM7 no differences were detected on the improvement of students' CT skills as measured by CCTT - Level X test; besides, some methodological barriers related to the nature and application of the instrument were identified (see below, in 'Reported difficulties' section).

It was not always clear how or which specific skills and dispositions were promoted and measured through specific CT approaches, strategies and/or assessment instruments - which are, in general, slightly commented or addressed on the analysed papers. Moreover, there were no mid/long-term interventions allowing a longitudinal assessment of the evolution of students' CT skills and dispositions. Also, no studies were found evaluating the generalization of students' CT skills and dispositions to other contexts, in the labour market or in everyday life, not even into other course subjects within their BA or MA degrees.

\subsection{Reported Difficulties}

Several difficulties, challenges and barriers have been identified that may be categorized as:

- Methodological $(n=10)$ - e.g. regarding the study design or data collection process and the need for deeper and thorough studies (G3, G12, STEM11, STEM12, SS5 G16, STEM3, BS2); the use and application of the CCT Test to measure CT skills [which reputably presents out of everyday context scenarios and is excessively long (STEM7, G2)], or technical issues with the use of online tools (SS9);

- Pedagogical $(n=7)$ - concerning the difficulty to change and encourage the students' habits and dispositions for active learning approaches (BS5; G1; G3), the lack of teachers' pedagogical knowledge in assessing CT (G1, BS1 and STEM7), the activity design and its perceived utility (G1, G3, G5), or the need for additional resources to support learning (G5, G6);

- Organizational $(n=7)$ - related to the workload to design, develop, manage and evaluate CT interventions (BS2, BS5, BS12, G1, G5, G6, G12). 


\section{Discussion and Conclusions}

The present literature review on empirical educational interventions for CT development in HE students shows that research on CT interventions in Portuguese Higher Education is gradually increasing, possibly reflecting the growth of teachers committed with the implementation of $\mathrm{CT}$ teaching/learning practices. The reported works tend to be based mostly on an immersive CT approach, in which CT principles are not made explicit to the students, assuming that the skills will be acquired once engaged in the subject matter instruction. However, according to Saiz \& Rivas (2017) the clearly identification and definition of CT skills to be developed is a crucial element for the effective success of CT interventions, to be recognized by the students and taught directly by the instructor. The national HE teachers in general are still not well prepared today to implement and develop strategies which purposefully and effectively foster the CT skills and dispositions in their students (Vieira, Tenreiro-Vieira \& Martins, 2011). Different reasons may explain this situation, including the lack of institutional support (Ennis, 2016), the educational culture persisting in $\mathrm{HEl}$ (relying on short-term memorization, focused in getting high grades) (DiCarlo, 2009), or the lack of teachers' training for CT development across the curricula (Franco \& Almeida, 2017).

Secondly, the majority of the CT interventions and strategies reported are based on active and collaborative learning approaches, in which prevail the self-study and dialogue using authentic situations, as well as a combination of different strategies, namely: lecture discussions (argumentation), peer review, problem solving (inquiry), questioning, subject-matter tasks, case study or project-based learning. The majority of CT strategies are student-centered (requiring students' deep engagement in the activities and during the process), and have positively impacted students' motivation and engagement to learn. It seems that strategies oriented to CT and/or the use of CTdriven materials are crucial factors for the effectiveness and success of students' CT development. In this context, the teacher's role as facilitator, guide and monitor of the students' learning, together with his/her pedagogical knowledge is of outmost importance (Abrami et al., 2015; Silva et al., 2016).

Thirdly, the majority of the analysed studies only presented positive results at the CT cognitive level (e.g. analysis, synthesis, evaluation, explanation, questioning and argumentation), undervaluing the importance of CT dispositions for reflection [making students aware that CT is only developed with considerable practice and effort (Saiz \& Rivas, 2017)]. This is an important concern, suggesting that educators may be neglecting teaching and modelling CT dispositions in the classroom. It may seem as though Portuguese HE teachers are not educating their students to be critical thinkers, independently of their intellectual skills (Hamby, 2015). Knowing that CT dispositions are so much valued by the business world and organizations (Dumitru, 2017), we need to 
particularly reflect on how to bridge CT education in HEl curricula to the societal or labour market needs. Are we, in Portuguese HEl, promoting a CT education coping with the societal and workplace challenges? Even in the studies using CT interventions with authentic situations and different materials based on real world scenarios, there are no evidence of University-Business cooperation. Also, as the CT practices and interventions were carried out in a classroom environment, one could question which practical results of CT transfer to other contexts were obtained or if these practices indeed triggered any type of critical action (Barnet, 2015).

Fourthly, some publications failed to present a clear link between the reported interventions used to promote CT skills and the specific practices used. While teachers reported having difficulties to assess students' $\mathrm{CT}$, evidence is lacking regarding the ways the adopted strategies, used for short periods of time, helped promoting specific CT skills and dispositions. The methods used to describe and assess CT results were limited or just slightly commented in some of the publications - most of them were based on teachers' and students' perceptions. It seems possible that Portuguese HEI fail to recognize the limitations of short-term courses, which together with few interventions in scattered subjects within a course, may constitute a serious obstacle to the reform of instruction (Paul, 2005). Studies related to permanency or generalization of CT skills and dispositions (Saiz \& Rivas, 2017) were not found. Also, few studies used control groups, and the reported differences in CT were mainly based in a pre/post statistic, excluding other possible explanations for the reported improvements, e.g. maturation, social interaction, drop-outs, familiarity with the test, desire to improve (Ennis, 2016). So, we need to keep investigating the impact of academic experience in students' CT, in order to map the factors that influence it (Franco \& Almeida, 2017). Different research (and interventions) designs (e.g. longitudinal and experimental studies with control groups) are desirable, along with the adoption of adequate assessment instruments other than the CCTT - Level X, including the evaluation of situations requiring decision making or problem-solving process, preferably related to the students' everyday life (Franco \& Almeida, 2017).

Finally, it is important to understand to which extent the reported difficulties can be overcome and what are the roles of the different stakeholders in the whole process of pedagogical, cultural and organizational change. Here, major concerns were related to the lack of time, teachers' workload, students' motivation and learning assessment. Development of active learning strategies, in particular targeting CT skills, are time-consuming and demand an increased workload from teachers whether to prepare the activities, assess students' performance or give timely feedback. Several topics drawing attention need further discussion, such as: "How can teachers start implementing CT practices and interventions, with little time and excessive workload?"; "How can students be motivated to engage in CT development? To what extent the 
use of different materials or the adoption of different CT strategies positively impact motivation?"; "How can teachers align specific CT aims with different CT approaches, interventions, strategies, and assessment instruments?".

\section{Limitations and Future Work}

As far as we are aware, this was the first systematic literature review on CT educational practices adopted by Portuguese Higher Education teachers. It contributes to the inventory and characterization of strategies to promote CT education; it also results on a set of important considerations to be taken into account for any future agenda.

Notwithstanding, different research limitations were found, namely the inability to access some of the publications initially selected. Also, other empirical studies reporting CT interventions in the Portuguese Higher Education context may have eluded the initial search pool because of the use of different field-related concepts and terminology, typical to a particular knowledge field (e.g. "clinical judgment" or "medical reasoning" in the Biomedicine field) or a different language (like Spanish or French), suggesting the need for field-driven literature reviews. Besides, a further thorough analysis may be performed to better understand the relation between specific dimensions and their effectiveness on students' CT development (e.g. CT approaches with Learning Results; CT materials with Learning Results; CT strategies with Learning Results; Reported Difficulties with Learning Results). We plan to carry-out different interviews to higher education teachers at the national level, and also to extend this characterization to other European countries in which CT is promoted in higher education. This constitutes part of the future research agenda of the CRITHINKEDU project.

\section{Acknowledgment}

This work was supported by the 'Critical Thinking Across the European Higher Education Curricula - CRITHINKEDU' project (ref. no. 2016-1-PT01-KA203-022808), funded by the European Commission/EACEA, through the ERASMUS + Programme. https://Crithinkedu.utad.pt, crithinkedu@utad.pt, https://www.facebook.com/crithinkedu.

Note: Availability of data - The complete list of papers retrieved in databases search, together with the reasons for non-eligibility and the rubrics used for paper assessment, are archived at http://bit. ly/2v286NP 


\section{References}

Abrami, P.C.; et al (2015). Strategies for Teaching Students to Think Critically: A Meta-Analysis. Review of Educational Research, 85(2), 275-314.

Arum, R., \& Roksa, J. (2011). Academically adrift: Limited learning on college campuses. University of Chicago Press.

Barnett, R. (2015). A Curriculum for Critical Being. In M. Davies \& R. Barnett (Eds.), The Palgrave Handbook of Critical Thinking in Higher Education (pp. 63-76). New York: Palgrave Macmillan.

Bennett, J., Lubben, F., Hogarth, S., \& Campbell, B. (2005). Systematic reviews of research in science education: rigour or rigidity? International Journal of Science Education, 27(4), 387-406.

Biggs, J. B., \& Collis, K. F. (1982). Evaluating the Quality of Learning - the SOLO Taxonomy. New York: Academic Press.

De la Torre, S. (1991). Evaluación de la Creatividad. Madrid: Editorial Escuela Española.

DiCarlo, S. E. (2009). Too much content, not enough thinking, and too little FUN! Advances in Physiology Education, 33(4), 257-264.

Dominguez, C., Morais, E., Morais, F., Cruz, G., Lopes, J., Silva, H., Monteiro, M., Nascimento, M., Catarino, P., Payan-Carreira, R., \& Vieira, R. (2015). Pensamento Crítico na Educação: Desafios Atuais. Vila Real: UTAD.

Dumitru, D. (2017, May). What employers think about critical thinking? Preliminary research report. Paper presented at the 6th International Conference EdProf 2017 - "Professionalism in education", Bucharest University of Economic Studies, Romania.

Ennis, R. (1989). Critical Thinking and Subject Specificity: Clarification and Needed Research. Educational Research, 18, 4-10

Ennis, R. (1991). Critical Thinking: A Streamlined Conception. Teaching Philosophy, 14(1), 5-24

Ennis, R. (2016). Critical Thinking Across the Curriculum: A Vision. Topoi, 1-20

Facione. P. A. (1990). Critical Thinking: A Statement of Expert Consensus for Purposes of Educational Assessment and Instruction. Research Findings and Recommendations. Millbrae, CA: The California Academic Press.

Franco, A., \& Almeida, L. (2017). Definição e medida do Pensamento Crítico. In L. S. Almeida (Org.), Criatividade e Pensamento Crítico: Conceito, Avaliação e Desenvolvimento (pp. 107-132). Braga: Centro de Estudos e Recursos em Psicologia

Hamby, B. (2015). Willingness to Inquire: The Cardinal Critical Thinking Virtue. In M. Davies \& R. Barnett (Eds.), The Palgrave Handbook of Critical Thinking in Higher Education (pp. 77-87). New York: Palgrave Macmillan.

McAleese, M., et al (2013). Report to the European Commission on Improving the quality of teaching and learning in Europe's higher education institutions. Luxembourg: Publication Office of the European Union. 
Nelson, M. M., \& Schunn, C. D. (2009). The Nature of Feedback: How Different Types of Peer Feedback Affect Writing Performance. Instructional Science, 27(4), 375-401.

Nosich, G. (2011). Aprender a Pensar Criticamente. Porto: Universidade Católica.

Payan-Carreira, R., Dominguez, C., Monteiro, M.J., Rainho, C., (2016). Application of the adapted FRISCO framework in case-based learning activities. Revista Lusófona de Educação, 32, 173-189.

Paul, R. (2005). The State of Critical Thinking Today. New Directions for Community Colleges, 2005(130), 27-38

Saiz, C., \& Rivas, S. (2017). Desarollo del Pensamiento Crítico. In L. S. Almeida (Org.), Criatividade e Pensamento Crítico: Conceito, Avaliação e Desenvolvimento (pp. 133-179). Braga: Centro de Estudos e Recursos em Psicologia

Scheffer, B. K., \& Rubenfeld, M. G. (2000). A consensus statement on critical thinking in nursing. Journal of Nursing Education, 39(8), 352-359.

Schwab K., \& Samans, R. (2016). The future of jobs: Employment, skills and workforce strategy for the fourth industrial revolution. World Economic Forum. Geneva: Switzerland.

Silva, H., Lopes, J., Dominguez, C., Payan-Carreira, R., Morais, E., Nascimento, M.M., Morais, F. (2016). Fostering critical thinking through peer-review between cooperative learning groups. Revista Lusófona de Educação, 32, 31-45.

Soares, D., Franco, A., \& Dias, D. (2017). Translating Critical Thinking Skills to Higher Education Practices. In Proceedings of the 11th International Technology, Education and Development Conference (INTED 2017) (pp. 9195-9200). Valência: Spain

Tiruneh, D. T., Verburgh, A., \& Elen, J. (2014). Effectiveness of Critical Thinking Instruction in Higher Education: A Systematic Review of Intervention Studies. Higher Education Studies, 4(1), 1-17

Vieira, R. M., Tenreiro-Vieira, C., \& Martins, I. P. (2011). Critical thinking: Conceptual clarification and its importance in science education. Science Education International, 22(1), 43-54.

Gonçalo Cruz

Bolseiro de Investigação no Projeto "CRITHINKEDU - Critical Thinking Across the European Higher Education Curricula" (2016-1-PT01-

KA203-022808),

Universidade de Trás-os-Montes e Alto Douro (UTAD), Vila Real, Portugal Email: goncaloc@utad.pt

Rita Payan-Carreira Professora Auxiliar com Agregação no Dept. de Zootecnia - Universidade de Trás-os-Montes e Alto Douro (UTAD. Centro de Ciência Animal e Veterinária (CECAV), UTAD. Email: rtpayan@gmail.com 


\section{Caroline Dominguez}

Professora Auxiliar no Dept. de Engenharias, Universidade de Trás-os-Montes e Alto Douro (UTAD). LabDCT/CIDTFF - Laboratório de Didática de Ciências e Tecnologia / Centro de Investigação Didática e Tecnologia na Formação de Formadores,

Universidade de Aveiro. CETRAD-Center of Transdisciplinary Development Studies (UTAD).

Email: carold@utad.pt

Correspondência

Caroline Dominguez

Escola de Ciência e Tecnologia Departamento de Engenharias, Polo 1

Quinta de Prados 5000-801 Vila Real

Data de submissão: Junho 2017

Data de avaliação: Outubro 2017 Date de publicação: Dezembro 2017 